\title{
Study on the impact of livelihood capital on farmers' choice of forestland management mode --a case study of Fujian province
}

\author{
Jing $\mathrm{Li}^{1, \mathrm{a}}$, Qin Chen ${ }^{* 2, \mathrm{~b}}$ \\ ${ }^{1}$ College of economics, Fujian agricultural and Forestry University Fujian commercial college Fuzhou China \\ ${ }^{2}$ College of economics, Fujian agricultural and Forestry University Fuzhou China
}

\begin{abstract}
Based on the survey data of 300 households in Fujian province, the system of farmers' choice of forestland management mode was constructed by using the framework of sustainable livelihood analysis, and the impact of livelihood capital on farmers' choice of forestland management mode was analyzed by using binary logistic model. The research shows that the factors of livelihood capital have different impact on the choice of forestland management mode. On this basis, the author puts forward some countermeasures to encourage farmers to improve their livelihood capital capacity, develop scale management and reduce their dependence on forestland income.
\end{abstract}

\section{INTRODUCTION}

A new round of collective forest tenure reform was initiated from Fujian and other provinces in 2003. With the development of industrialization and new urbanization, the livelihood capital of farmers has changed a lot. The change of livelihood capital changes the dependence degree of forestland, and then affects the choice of forestland management mode of farmers. The collective forestland management mode of rural households in Fujian province mainly consists of single-family management (with a single family as the forest management unit) and co-family management (with two or more family manage the forest together). Different management modes affect the utilization efficiency of forestland. Therefore, based on the perspective of farmers' livelihood capital, this paper explores the factors of farmers' choice of forestland management mode, and then systematically proposes appropriate measures for forestland management. Meanwhile, it can also provide some useful experience for the cultivation and development of new forest management subjects.

Academic research on livelihood capital focuses on the impact of livelihood capital on livelihood strategies and income $^{[1]}$. The analysis of forestland management mode mainly focuses on the types of forestland management ${ }^{[2]}$ and the factors influencing the choice of forestland singlefamily management mode ${ }^{[3]}$. The existing literature mainly studies the factors affecting the choice of farmers' forest management mode from one aspect of their livelihood capital and less studies the impact factors of farmers' choice of forestland management mode. This paper attempts to explore the impact of sustainable livelihood capital on the choice of forest management model.

\section{THEORETICAL ANALYSIS FRAMEWORK}

The sustainable living capital theory was developed by the UK International Development Agency. It includes natural capital, human capital, financial capital, material capital and human capital ${ }^{[4]}$. Natural capital refers to the stock of natural resources owned by farmers, mainly including the specific situation of forest resources ${ }^{[5]}$. Material capital refers to the capital that can bring benefits to farmers and meet their needs, including the living facilities and production equipment that farmers have for living and development ${ }^{[6]}$. Human capital mainly refers to the age, education level, livelihood skills and health status of the workers. Financial capital refers to the financial security status such as the annual income possessed by peasant households ${ }^{[7]}$. Social capital refers to the social resources that farmers can use $\mathrm{e}^{[8]}$.

Due to the long cycle of forestry production and the choice of farmers' forestland management mode, it is necessary to comprehensively consider the current situation of livelihood capital owned by families and focus on the combination of current and long-term interests of families.

\section{DATA SOURCE AND VARIABLES SELECTION}

\subsection{Data Source}

ae-mail: quietlijing@126.com ºbe-mail: 956585977@qq.com 
The data of this paper comes from the survey of typical areas in Fujian. Fujian province is the experimental area of collective forest tenure reform, and its forest coverage rate ranks first in China for many years. Fujian's natural field". The importance of forestland to farmers is selfevident. The utilization pattern of forestland is related to the improvement of household income and welfare.

From July to August 2019, the research group conducted household survey in Fujian collective forest area, which mainly investigated household livelihood capital and forestry management information. In 10 counties (cities) of collective forest reform monitoring, 5 sample villages were selected from each county (city), and each sample village was selected based on the principle of combination of classic sampling and random sampling. A total of 300 farmers were interviewed and 282 questionnaires were valid.

\subsection{Variable Selection and Measure} resources are known as "eight mountains, one water, one

Combined with the actual situation of the research area, this paper intends to study the impact of livelihood capital on the choice of farmers' forestland management mode from the perspective of livelihood capital. The management mode of rural households in Fujian province mainly focuses on single-family management and cofamily management. The five components of livelihood capital are measured by different indicators, as is shown in table 1. Natural capital is measured by the forestland area of each family and the furthest distance between forestland and road. Human capital is measured by the household head's age, years of education, whether he/she has participated in skill training, health status and the total family population. Physical capital is measured in terms of productive fixed assets and housing types. Financial capital is measured by annual household income and access to forestry subsidies. Social capital is measured by whether family member joins forestry cooperation organization or association, whether family member has village cadre. Both single- family mode and co- family mode are affected by the difficulty of applying for cutting quota, which is taken as the control variable.

Table1. VARIABLE ASSIGNMENT TABLE

\begin{tabular}{|c|c|c|c|}
\hline dimension & variables & symbol & $\begin{array}{c}\text { Variable assignment and variable } \\
\text { definition }\end{array}$ \\
\hline dependent variable & Forest management mode & $\mathrm{y}$ & $\begin{array}{l}\text { Single-family mode }=1, \text { co-family } \\
\text { mode }=0\end{array}$ \\
\hline \multirow{4}{*}{ Human capital } & The householder age & $\mathrm{x}_{1}$ & Continuous variable \\
\hline & Years of education for householder & $\mathrm{x}_{2}$ & Continuous variable \\
\hline & Skills training & $\mathrm{x}_{3}$ & yes $=1$, no $=0$ \\
\hline & Total family population & $\mathrm{x}_{4}$ & Continuous variable \\
\hline \multirow[b]{2}{*}{ Natural capital } & Area of forest land (MU) & $\mathrm{X}_{5}$ & Continuous variable \\
\hline & $\begin{array}{l}\text { The longest distance between forest } \\
\text { land and road }\end{array}$ & $\mathrm{x}_{6}$ & excellent $=1$, good $=0.6$, bad $=0.3$ \\
\hline \multirow{2}{*}{ Physical capital } & Productive fixed assets & $\mathrm{x}_{7}$ & $\begin{array}{c}\text { car }=1, \text { tractor }=0.8, \text { Agricultural } \\
\text { vehicle }=0.6\end{array}$ \\
\hline & Housing types & $\mathrm{x}_{8}$ & $\begin{array}{c}\text { brick }=1, \text { Brick and tile }=0.8, \text { Brick } \\
\text { and wood }=0.6\end{array}$ \\
\hline \multirow[t]{2}{*}{ Financial capital } & $\begin{array}{l}\text { Annual family income (ten thousand } \\
\text { RMB) }\end{array}$ & $\mathrm{X}_{9}$ & Continuous variables \\
\hline & Opportunities for forestry subsidies & $\mathrm{x}_{10}$ & yes $=1$, no $=0$ \\
\hline \multirow{2}{*}{ Social capital } & $\begin{array}{c}\text { Whether to participate in the Forestry } \\
\text { Cooperation Organization }\end{array}$ & $\mathrm{x}_{11}$ & yes $=1$, no $=0$ \\
\hline & $\begin{array}{l}\text { the family members have village } \\
\text { cadres }\end{array}$ & $\mathrm{x}_{12}$ & yes $=1$, no $=0$ \\
\hline Control variable & $\begin{array}{l}\text { The difficulty of applying for cutting } \\
\text { quota }\end{array}$ & $\mathrm{x}_{13}$ & difficult $=1$, easy $=0$ \\
\hline
\end{tabular}

\section{MODEL SELECTION AND EMPIRICAL RESULTS ANALYSIS}

\subsection{Model selection}

Since the Forest management mode is single- family management and co- family management, the binary logistic regression model is selected to analyze the impact of livelihood capital on the choice of farmers' forestland mode. Farmers' choice of forest mode $\mathrm{f}=$ (farmers' livelihood capital) $=\mathrm{f}$ (human capital, natural capital, material capital, financial capital, social capital, etc.), the specific model is as follows:

$$
\operatorname{Logit}\left(\rho_{i}\right)=\ln \frac{\rho_{i}(y=1)}{1-\rho_{i}(y=1)}=\beta_{0}+\sum_{i=1}^{n} \beta_{i} \cdot x_{i}+\varepsilon
$$

pi represents the probability of occurrence of single-family

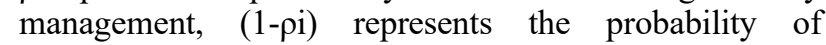
occurrence of co- family management, $\beta \mathrm{i}$ represents regression efficient, $\mathrm{xi}$ represents the respective variables, and $\varepsilon$ represents the residual term.

\subsection{Analysis of Empirical Results}

\subsubsection{Descriptive statistics of the data}


Table2. DESCRIPTIVE STATISTICS OF VARIANLES

\begin{tabular}{|c|c|c|c|c|c|}
\hline Variable & Obs & Mean & Std.Dev. & Min & Max \\
\hline $\mathrm{y}$ & 282 & 0.7092199 & 0.4549296 & 0 & 1 \\
\hline $\mathrm{x}_{1}$ & 282 & 53.84043 & 8.500328 & 40 & 83 \\
\hline $\mathrm{x}_{2}$ & 282 & 8.361702 & 2.347943 & 2 & 16 \\
\hline $\mathrm{x}_{3}$ & 282 & 0.2092199 & 0.4074748 & 0 & 1 \\
\hline $\mathrm{x}_{4}$ & 282 & 4.882979 & 1.133662 & 1 & 9 \\
\hline $\mathrm{x}_{5}$ & 282 & 17.47011 & 15.0331 & 2.8 & 100 \\
\hline $\mathrm{x}_{6}$ & 282 & 5.019149 & 2.729486 & 0.5 & 30 \\
\hline $\mathrm{x}_{7}$ & 282 & 0.741844 & 0.1729608 & 0.6 & 1 \\
\hline $\mathrm{x}_{8}$ & 282 & 0.9439716 & 0.1032351 & 0.6 & 1 \\
\hline $\mathrm{x}_{9}$ & 282 & 8.763121 & 4.18032 & 1.2 & 30 \\
\hline $\mathrm{x}_{10}$ & 282 & 0.2588652 & 0.4387901 & 0 & 1 \\
\hline $\mathrm{x}_{11}$ & 282 & 0.1914894 & 0.3941727 & 0 & 1 \\
\hline $\mathrm{x}_{12}$ & 282 & 0.0638298 & 0.2448841 & 0 & 1 \\
\hline $\mathrm{x}_{13}$ & 282 & 0.822695 & 0.3826056 & 0 & 1 \\
\hline
\end{tabular}

70.92 percent of the farmers choose the single-family management mode, and 29.09 percent choose the cofamily management mode as shown in table 2 . The average age of the household head is 53.84 years old, and the year of average education is 8.4 years. Most of the education level is junior high school. The proportion of farmers participating in skill training is relatively low. The average household population is 4.88 , with a certain proportion of labor participation. The average forest area is $17.47 \mathrm{mu}$, mostly belonging to small-scale forestry farmers. The furthest distance from the forestland to the road is $5.02 \mathrm{~km}$ on average, because the forestland belongs to the mountainous area. The forestland is far away from the road. In the fixed assets of households, the car, tractor and agricultural vehicle occupy certain proportion each. The family can buy appropriate vehicle to use according to their need. The buildings are mainly brick and tile structures. The household income of the family all reached 87,600 RMB. A considerable number of farmers received forestry subsidies, because the proportion of ecological public welfare forest in Fujian province is relatively high. With the encouragement and support of national policies, 19.15 percent of the surveyed households were involved in forestry cooperative organizations or associations. 6.38 percent of the respondents had served as village cadres. It is difficult for users to apply for logging quota.

\subsubsection{Analysis of regression results}

Table3. REGRESSION RESULTS OF LOGIT MODEL

\begin{tabular}{|c|c|c|c|c|c|}
\hline $\mathrm{y}$ & Coef. & Std. & Err. & $\mathbf{z}$ & $\mathbf{P}>|\mathbf{z}|$ \\
\hline $\mathrm{x}_{1}$ & 0.005741 & 0.0187149 & 0.31 & 0.759 & -0.030939 \\
\hline $\mathrm{x}_{2}$ & 0.1431748 & 0.0706463 & 2.03 & $0.043^{* *}$ & 0.0047106 \\
\hline $\mathrm{x}_{3}$ & -0.228256 & 0.3533191 & -0.65 & 0.518 & -0.920749 \\
\hline $\mathrm{x}_{4}$ & 0.2434011 & 0.1376067 & 1.77 & $0.077^{*}$ & -0.026303 \\
\hline $\mathrm{x}_{5}$ & 0.0118989 & 0.0111291 & 1.07 & 0.285 & -0.009914 \\
\hline $\mathrm{x}_{6}$ & 0.1319134 & 0.0732623 & 1.8 & $0.072^{*}$ & -0.011678 \\
\hline $\mathrm{x}_{7}$ & -0.1551507 & 0.8984848 & -0.17 & 0.863 & -1.916148 \\
\hline $\mathrm{x}_{8}$ & -4.156596 & 1.766323 & -2.35 & $0.019 * * *$ & -7.618526 \\
\hline $\mathrm{x}_{9}$ & -0.1298204 & 0.0428356 & -3.03 & $0.002^{* * *}$ & -0.213777 \\
\hline $\mathrm{x}_{10}$ & 0.6804073 & 0.3559872 & 1.91 & $0.056^{*}$ & -0.017315 \\
\hline $\mathrm{x}_{11}$ & -1.222777 & 0.3649302 & -3.35 & $0.001 * * *$ & -1.938027 \\
\hline $\mathrm{x}_{12}$ & -1.158718 & 0.5513478 & -2.1 & $0.036^{* *}$ & -2.23934 \\
\hline $\mathrm{x}_{13}$ & -0.5294419 & 0.4177817 & -1.27 & 0.205 & -1.348279 \\
\hline
\end{tabular}

There is a significant difference between the factors of household livelihood capital and the choice of the modes as shown in table 3. In peasant households' human capital, the age coefficient of household head is positive, indicating that the older the farmer is, the more inclined he is to choose single-family mode. However, as most of the sample farmers were middle-aged, the impact of this variable on the selection of forest patterns was not significant. The coefficient of skill training is negative, but not significant, indicating that the more involved in skill training, the more inclined to choose co-family mode. We can combine technology, labor and capital to achieve greater benefits. The education passed the significance test of 5 percent statistical level, and the coefficient was positive, indicating that the higher the education level, the more inclined to choose single-family management. The total family population passed the significance test of 10 percent statistical level, and the coefficient was positive, indicating that the larger the family population is, the more likely farmers are to choose single-family management. Because more labor can be engaged in forestry production activities.

Among the natural capital, the forest area owned by farmers did not pass the significance level test, which may be because the average household forest area of surveyed farmers is relatively small. This factor is not the main factor for farmers to choose the forestland mode. The furthest distance between forestland and road passed the statistical significance level test of 10percent, and the coefficient was positive. It shows that the transportation convenience of forest land in mountainous areas has a great impact on the mode of single-family or co- family. Convenient road transport conditions is crucial for the mode of a single family.

Whether a family owns a car, a tractor or an agricultural vehicle has no significant impact on the choice of the mode among the material capital. The housing type of households passed the test at the statistical level of 1percent, 
and the coefficient was negative. It shows that the housing type can more comprehensively reflect the overall physical capital level of farmers, and determine the type of farmers' forestland mode. The housing type of brick structure of households corresponds to the higher household asset level, and they are more inclined to choose the co-family mode, which can save more labor and engage in the non-forest industry with higher efficiency.

Among the financial capital, the total annual family income passed the test at the statistical level of 1percent, and the coefficient was negative, indicating that the higher the household income, the more likely the farmers were to choose co-family mode. Co-family mode can ensure the family more labor force engaged in non-agricultural employment and ensure the family higher income. The obtained forestry subsidy passed the test at the statistical level of 1percent, and the coefficient was positive, indicating that the more farmers received forestry subsidy, the more inclined they were to choose single-family management. In Fujian province, ecological forests account for a large part of the forest, and the government has been increasing subsidies for forestry. The singlefamily management mode can use forestry subsidy funds to subsidize production.

Among the social capital, whether to participate in forestry cooperative organizations or associations passed the test on the statistical level of 1percent, and the coefficient was negative. It indicates that farmers who participate in forestry cooperatives are more inclined to choose co-family management. Because this mode can obtain the help of more capital and information, and be advantageous to forestry management. Whether (has been or is currently) served as a village cadre has passed the test on the statistical level of 5percent, and the coefficient is negative, indicating that farmers with the experience of village cadres are more inclined to choose the co-family management mode.

\section{CONCLUSION AND POLICY IMPLICATIONS}

\subsection{Conclusion}

Based on the survey data of 282 households in Fujian province, this paper discusses the impact of livelihood capital on the choice of forestry modes. The order of impact on forestland management mode selection is: housing types (negative), whether to participate in cooperative (negative), as a village cadres (negative), enjoy forestry subsidy (positive), family population (positive), education (positive), forestland distance from road (positive), total family income (negative). However, the age of household head, the family's forestland area, the productive fixed assets owned, the skill training of farmers and the difficulty of applying for logging quota have little impact on the choice of forestland mode.

\subsection{Policy Implications}

The degree of impact of livelihood capital projects is different whether farmers choose single-family mode or co-family mode. The moderate scale management of forestland is a big trend of forestry development in the future. How to cultivate new forestry management body needs to expand the scale of forestry management on the basis of the farmer's existing mode. Different farmers have different livelihood capital. It needs to increase the famers' income, improve the education level of workers, improve the skills of non-agricultural employment of workers. The government can make a feasible plan only by deeply understanding the impact degree and direction of these factors on the choice of forestland management mode,. The government can achieve a rational utilization of forestry resources and improve the production efficiency of forestry industry.

\section{Acknowledgment}

This research was financially supported by science and technology innovation special fund project of Fujian agricultural and forestry university (CXZX2017414) ---Research on the influence of different livelihood strategies on forest species selection intention of Fujian forestry farmers.

\section{References}

1. $\mathrm{Wu}$ J, Selection of different forestry operation modes and analysis of influencing factors. Journal of Beijing forestry university vol.13, pp. 13-21,2013

2. $\mathrm{Wu} \mathrm{Y}, \mathrm{Choice}$ of livelihood capital and livelihood strategy for farmers. journal of south China agricultural university, vol. 2, pp 57-66, 2015

3. Dai $\mathrm{J}$ and $\mathrm{Li} \mathrm{H}$, Analysis on influencing factors of forest management model selection from the perspective of post- forest tenure reform forestry economy vol. 7, pp :50-56,2015

4. Li H, Impact of heterogeneity of livelihood capital on farmers' farmland transfer behavior (J). Resources and environment in the Yangtze river basin vol. 2, pp: 220-227,2017

5. Liu B, Research on the influencing factors of the choice of single-family business model in forestry and agriculture (J) vol.4, pp: 23-28,2017

6. Liu W, Measure of change of livelihood capital of farmers under the mode of "company + farmer" $(\mathrm{J})$ journal of Yunnan agricultural university vol.4, pp: 97-104,2019

7. Zhang Z, Analysis on the impact of livelihood capital on farmers' participation in the decision of returning farmland (J) resources and environment in arid areas vol. 4, pp: 23-29,2019

8. Li C, Poverty alleviation relocation in transits, inequality between livelihood capital and household income agricultural technical economy vol. 7, pp: 5267,2019 